\title{
In vivo and in vitro anti-hepatitis B virus activity of total phenolics from Oenanthe javanica
}

\author{
Yan-Quan Han ${ }^{\text {a,b }}$, Zheng-Ming Huang ${ }^{\mathrm{b}, * *}$, Xin-Bo Yang ${ }^{\mathrm{c}, *}$, He-Zhi Liu ${ }^{\mathrm{d}}$, Guang-Xia Wu ${ }^{\mathrm{a}}$ \\ a Research Center for Eco-environmental Sciences, Chinese Academy of Sciences, Beijing 100085, PR China \\ b 302 Hospital of People's Liberation Army (PLA), Beijing 100039, PR China \\ c 301 Hospital of PLA, Beijing 100853, PR China \\ d Institute for Drug and Instrument Control of Health Department, GLD of PLA, Beijing 100071, PR China
}

\section{A R T I C L E I N F O}

\section{Article history:}

Received 1 September 2007

Received in revised form 11 December 2007

Accepted 30 March 2008

Available online 14 April 2008

\section{Keywords:}

Oenanthe javanica

Phenolics

Anti-HBV activity

Hep G2.2.15 cells

Duck hepatitis B virus

\begin{abstract}
A B S T R A C T
The traditional Chinese medicine Oenanthe javanica (OJ) has been used for many years, mainly for the treatment of inflammatory conditions including hepatitis. In this study, human hepatoma Hep G2.2.15 cells culture system and duck hepatitis B virus (DHBV) infection model were used as in vivo and in vitro models to evaluate the anti-HBV effects of total phenolics from Oenanthe javanica (OJTP). The HBeAg and HBsAg concentrations in cell culture medium were determined by using the enzyme immunoassay kit after Hep G2.2.15 cells were treated with OJTP for $9 \mathrm{~d}$. DHBV-DNA in duck serum was analyzed by dot blot hybridization assay. In the cell model, OJTP could dose-dependently inhibit the production of the HBeAg and HBsAg, and the inhibition rates of OJTP on HBeAg and HBsAg in the Hep G2.2.15 cells were $70.12 \%$ and $72.61 \%$ on day 9 , respectively. In the DHBV infection model, OJTP also reduced HBV DNA level in a dose-dependent manner. The DHBV-DNA levels decreased significantly after the treatment with $0.10 \mathrm{~g} \mathrm{~kg}^{-1} \mathrm{~d}^{-1}$ and $0.20 \mathrm{~g} \mathrm{~kg}^{-1} \mathrm{~d}^{-1}$ OJTP. The inhibition of the peak of viremia was at the maximum at the dose of $0.20 \mathrm{~g} \mathrm{~kg}^{-1} \mathrm{~d}^{-1}$ and reached $64.10 \%$ on day 5 and $66.48 \%$ on day 10 , respectively. Histopathological evaluation of the liver revealed significant improvement by OJTP. In conclusion, our results demonstrate that OJTP can efficiently inhibit HBV replication in Hep G2.2.15 cells line in vitro and inhibit DHBV replication in ducks in vivo. OJTP therefore warrants further investigation as a potential therapeutic agent for HBV infections.
\end{abstract}

(c) 2008 Elsevier Ireland Ltd. All rights reserved.

\section{Introduction}

Traditional Chinese medicine (TCM) has been widely used to treat chronic liver diseases and its therapeutic benefits have been recognized for centuries. Although there is still lack of evidence for clarification of their typical mechanisms, different from pharmaceutical chemicals, it is still widely accepted by people from East Asia and beginning to be accepted by the rest of the world. In recent years, many controlled trials have been done to investigate their efficacy (Liu et al., 2001) and the results indicate that some Chinese medicinal herbs may work in hepatitis B virus (HBV). One of them is Oenanthe javanica (OJ) from umbelliferate which has been used in treatment of liver diseases for many years (Wei, 1963; Li, 1978), and it is also effective in hepatitis jaundice, trichorrhea, eliminating pathogenic wind and diabetes (Huang and Yang, 2006), etc. Mod-

\footnotetext{
* Corresponding author. Tel.: +86106693 7576 .

** Corresponding author. Tel.: +86 1066933233 .

E-mail addresses: huang_zhengming@sohu.com (Z.-M. Huang), yang_xinbo@yahoo.com (X.-B. Yang).
}

ern research has witnessed that $\mathrm{OJ}$ has effects of hepatoprotective and can be used for inhibiting hepatitis virus B, lowering blood pressure, relieving arrhythmia and anti-anaphylaxis (Huang et al., 1991, 2001a,b; Yang et al., 1998).

Our previous studies show that OJ preparation and OJ water extract have hepatoprotective effect on different HBV animal model such as rat, mouse and duck (Huang et al., 1997a,b, 2001a,b). These studies have indicated that $\mathrm{OJ}$ was an effective antiviral medicine in treating HBV. However, the active part of OJ anti-HBV is still unknown. Under the foundation of previous studies, we separated total phenolics from OJ using modern techniques, which comprises approximately $1.50 \%$ in the whole plant content. In this study, we aim to investigate the anti-hepatitis activity of OJTP in Hep G2.2.15 cells in vitro and DHBV infection in a duck model in vivo.

\section{Materials and methods}

\subsection{Preparation of OJTP}

OJ was collected from the Kai Yuan, Liao Ning Province in china, in autumn 2006 and identified by Prof. Hui-zhong XIAO, 
Department of Phytochemistry, Yanbian Medical University, China. Dried whole plant was cut into pieces and extracted with $75 \%$ ethanol under reflux at $70^{\circ} \mathrm{C}$ for three times. The resulting extract was filtered and the supernatant was concentrated at reduced pressure by a rotary evaporate, and were fractionated by distilled water and ethanol gradient of column chromatography in polyamide. Whole extract with a yield of $1.50 \%$ was obtained by pressurereduced evaporation and vacuum drying from ethanol gradient. The total phenolics content of OJTP was determined spectrophtotometrically with Folin-Ciocalteu reagent using gallic acid as calibration standard (Slinkard and Singleton, 1977; Sadasivam and Manikam, 1992). Absorbance was measured at $750 \mathrm{~nm}$. The result was expressed as $g$ of gallic acid equivalents (GAE) per $100 \mathrm{~g}$ of OJTP ( $\mathrm{g}$ GAE/100 g OJTP). The results of quantification indicated that OJTP had high content of phenolic compounds that made up OJTP $(52.3 \mathrm{~g}$ GAE/100 g OJTP).

In addition, the content of chlorogenic acid (CHA) in OJTP was determined by reverse phase-high performance liquid chromatography (RP-HPLC) (Huang and Yang, 2006) in comparison with authentic CHA, and the results indicated that chlorogenic acid was one of phenolic components in OJTP whose content was $4.98 \%$.

\subsection{Animals and reagents in experiment}

Beijing ducklings within $1 \mathrm{~d}$ of hatching were obtained from an animal-breeding farm, Chinese Academy of Medical Sciences (SCXK-[Peking] 2002-2001, Peking, China). The animals received humane care according to the criteria outlined in the "Guide for the Care and Use of Laboratory Animals" prepared by the National Academy of Sciences and published by the National Institutes of Health.

3-[4,5]-Dimethylthiazol-2-yl-2,5-diphenyltetra-zolium bromide (MTT) were purchased from Sigma (St. Louis, MO). Minimum essential medium (MEM) was obtained from Gibco BRL (Gaithersburg, MD, USA). Fetal bovine serum (FBS) and G-418 were purchased from HyClone (Logan, Utah, USA). As the positive control drug, lamivudine (3TC) was obtained from GlaxoSmithKline (Suzhou, China). HBsAg and HBeAg enzyme immunoassay (EIA) kits were purchased from China Isotope Co. (Beijing, China).

\subsection{Cell culture and treatment}

Hep G2.2.15 (clonal cells derived from human hepatoma cell line G2) cells were provided by the Institute of Medicinal Biotechnology, Chinese Academy of Medical Sciences (Beijing, China). These cultures were derived from Hep G2 cells that were transfected with a plasmid vector containing G418-resistance sequences and 2 head-to-tail dimmers of the HBV genome. The cells were found to produce elevated levels of HBeAg and HBsAg. The Hep G2.2.15 cells were cultured in complete MEM (containing 10\% FBS, $100 \mathrm{kU} / \mathrm{L}$ benzylpenicillin, streptomycin, G-418, L-glutamine $0.03 \%, \mathrm{pH} 7.0$ ) in $75-\mathrm{cm}^{2}$ tissue culture flasks at $37{ }^{\circ} \mathrm{C}$ in a humidified $5 \% \mathrm{CO}_{2}$.

\subsection{Cytotoxicity assay}

The cytotoxicity of OJTP was analyzed by modified colorimetric assay (Mosmann, 1983). Hep G2.2.15 cells $\left(1.0 \times 10^{5}\right.$ cells/well) were seeded in 96-well/plates (Corning Inc., Corning, NY, USA) for $24 \mathrm{~h}$. After attachment to plates, the supernatants in each well were replaced very carefully with $100 \mu \mathrm{L}$ of fresh DMEM containing different concentrations $(0.05 \mathrm{~g} / \mathrm{L}, 0.10 \mathrm{~g} / \mathrm{L}, 0.20 \mathrm{~g} / \mathrm{L}, 0.40 \mathrm{~g} / \mathrm{L}, 0.80 \mathrm{~g} / \mathrm{L}$ and $1.20 \mathrm{~g} / \mathrm{L}$ ) of OJTP. Untreated cells were used as the control. Cells were treated or not treated with OJTP for $24 \mathrm{~h}, 48 \mathrm{~h}$ and $72 \mathrm{~h}$, and then $10 \mu \mathrm{L}$ of MTT at a final concentration of $5 \mathrm{mg} / \mathrm{mL}$ in PBS was added to each well and further incubated in $\mathrm{CO}_{2}$ incubator at $37^{\circ} \mathrm{C}$ for $4 \mathrm{~h}$. After $4 \mathrm{~h}$ of incubation, acid-isopropanol $(100 \mu \mathrm{L}$ of $0.04 \mathrm{~N}$ HCL in isopropanol) was added to all wells and mixed thoroughly to dissolve the dark blue crystals. After a few minutes at room temperature to ensure that all crystals were dissolved. The plates were read in a Dynatech MR580 Microelisa reader, using a test wavelength of $570 \mathrm{~nm}$. Plates were normally read within $1 \mathrm{~h}$ of adding the isopropanol. $\mathrm{TC}_{50}$ was the concentration that achieved $50 \%$ cytotoxicity against culture cells and was calculated in Bliss method (Yan-Ling et al., 2007).

\subsection{Determination of $\mathrm{HBs} A g$ and $\mathrm{HBeAg}$}

The Hep G2.2.15 cells were incubated in 24-well plates at a density of $1.0 \times 10^{5}$ cells $/ \mathrm{mL}$ in $1 \mathrm{~L}$ MEM medium containing $10 \%$ FBS. After $24 \mathrm{~h}$, the Hep G2.2.15 cells were treated with different concentrations of OJTP $(0.05 \mathrm{~g} / \mathrm{L}, 0.10 \mathrm{~g} / \mathrm{L}, 0.20 \mathrm{~g} / \mathrm{L}$ and $0.40 \mathrm{~g} / \mathrm{L})$ in serum-free medium. Cells grew in the presence of drugs for $9 \mathrm{~d}$ with changes of medium every $3 \mathrm{~d}$. After $6 \mathrm{~d}$ and $9 \mathrm{~d}$, Supernatant was collected and performed at $20^{\circ} \mathrm{C}$. The $\mathrm{HBsAg}$ and $\mathrm{HBeAg}$ in culture medium were simultaneously measured by EIA kits on days 6 and 9. This test was done twice under the same conditions.

\subsection{Animals and treatments}

Beijing ducklings within $1 \mathrm{~d}$ of hatching were inoculated intravenously with DHBV-DNA-positive serum from Shanghai ducks (0.2 mL/animal). After $7 \mathrm{~d}, 30$ ducklings infected with DHBV were randomly divided into five groups (6/group): the control group (normal saline); the positive control drug group (3TC, $\left.0.05 \mathrm{~g} \mathrm{~kg}^{-1} \mathrm{~d}^{-1}\right)$; and the OJTP $0.05 \mathrm{~g} \mathrm{~kg}^{-1} \mathrm{~d}^{-1}, 0.10 \mathrm{~g} \mathrm{~kg}^{-1} \mathrm{~d}^{-1}$ and $0.20 \mathrm{~g} \mathrm{~kg}^{-1} \mathrm{~d}^{-1}$ groups. Drugs were administered orally (bid) for $10 \mathrm{~d}$. DHBV-DNA was measured at days $0,5,10$ during treatment, and 3 after cessation of treatment starting from the10th day (day 13) by dot hybridization.

\subsection{Detection of $D H B V-D N A$}

Briefly, $50 \mu \mathrm{L}$ of duckling serum was spotted directly onto the nitrocellulose filters. DNA hybridization was initiated by adding a recently prepared DHBV ${ }^{32}$ PDNA probe at $1.0 \times 10^{6} \mathrm{cpm} / \mathrm{mL}$ using the same prehybridization procedure over night. Filters were washed twice in $1 \times \mathrm{SSC}(20 \times \mathrm{SSC}: 3 \mathrm{~mol} / \mathrm{L} \mathrm{NaCl}, 0.3 \mathrm{~mol} / \mathrm{L}$ sodium citrate, $\mathrm{pH} 7.0), 0.1 \% \mathrm{SDS}$ at $65^{\circ} \mathrm{C}$ for $2 \mathrm{~h}$, and $1 \times \mathrm{SSC}$ at room temperature for $30 \mathrm{~min}$ with gentle, constant agitation. The filter was dried and autoradiographed at $-70^{\circ} \mathrm{C}$ using X-ray film with an enhancer screen. After an autoradiographic image had been obtained, the filter was exposed in the phosphorimaging screen for $1-2 \mathrm{~h}$, and the samples were quantitated by FujixBAS1000 (Fuji, Tokyo, Japan); the percentage density of the phosphorimaging units was calculated.

\subsection{Histopathological examination of duck liver}

On day 13, each duckling was laparotomized to obtain the liver immediately after collecting blood from the leg vein. Fragments of the ducklings liver were fixed in $10 \%$ formalin solution, dehydrated with ethanol solution from $50 \%$ to $100 \%$, embedded in paraffin and cut into $5 \mu \mathrm{m}$ sections, and stained using hematoxylin and eosin dye for photomicroscopic observations.

\subsection{Statistics}

The data were expressed as mean \pm S.D. and analyzed by oneway repeated-measure ANOVA and $t$-test for comparisons between groups, $P<0.05$ were considered statistically significant. 


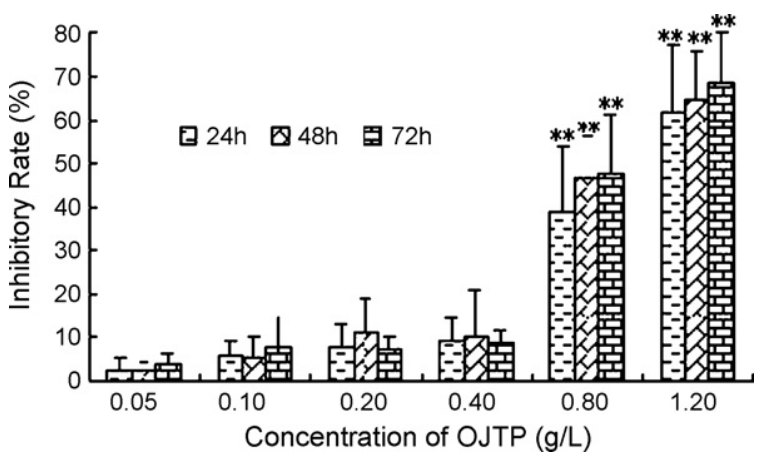

Fig. 1. The cytotoxicity of OJTP in Hep G2.2.15 cells. The inhibition of cell proliferation was measured by MTT assay method. OJTP could significantly inhibit the HepG2.2.15 cells above $0.40 \mathrm{~g} / \mathrm{L}$. The data represent mean \pm S.D. $(n=10)$. Symbols represent statistical significance. ${ }^{* *} P<0.01$ compared to control.

\section{Results}

\subsection{Cytotoxicity assay}

The growth of the Hep G2.2.15 cells in the presence of various concentrations of OJTP was examined. The results from the MTT test showed that there was no significant difference of cell viability between OJTP-treated groups whose concentrations were below $0.40 \mathrm{~g} / \mathrm{L}$ and control group (Fig. 1). OJTP inhibited the growth of Hep G2.2.15 cells at concentrations above $0.40 \mathrm{~g} / \mathrm{L}$ and $\mathrm{TC}_{50}$ for Hep G2.2.15 cells was $0.982 \pm 0.075 \mathrm{~g} / \mathrm{L}$. The cytotoxicity of OJTP was measured to determine the treatment concentrations in the Hep G2.2.15 cell culture system.

\subsection{Inhibitory effect of OJTP on HBeAg and HBsAg expression in 2.2.15 cells}

After $9 \mathrm{~d}$ of incubation, HBeAg and HBsAg produced in the culture medium were measured (Tables 1 and 2). The results showed that HBeAg and HBsAg of the cells incubated with OJTP were less than those of the control cells, and the concentration of $50 \%$ inhibition $\left(\mathrm{IC}_{50}\right)$ of $\mathrm{HBeAg}$ and $\mathrm{HBsAg}$ were about $0.315 \mathrm{~g}$ and $0.155 \mathrm{~g}$, $0.343 \mathrm{~g} / \mathrm{L}$ and $0.091 \mathrm{~g} / \mathrm{L}$ (data not shown), on days 6 and 9, respectively. The therapeutic indices, determined by $\mathrm{TC}_{50} \mathrm{vs}$. $\mathrm{IC}_{50}$, were about 3.11 and 6.34 for $\mathrm{HBeAg}, 2.86$ and 10.79 for $\mathrm{HBsAg}$, on days 6 and 9, respectively. OJOP-induced suppression of $\mathrm{HBeAg}$ and $\mathrm{HBsAg}$ production in Hep G2.2.15 cells was also reflected by the inhibition rate percentage (Tables 1 and 2). At $0.40 \mathrm{~g} / \mathrm{L}$, the inhibition rates of OJTP on HBeAg and HBsAg in the Hep G2.2.15 cells were $70.12 \%$ and $72.61 \%$ on day 9 , respectively. The inhibition rates of both HBsAg and HBeAg were time and dose dependent. It could also be observed that OJTP had a relatively stronger inhibition on HBsAg than $\mathrm{HBeAg}$.

\subsection{Inhibitory effect of OJTP DHBV-DNA}

The anti-HBV activity of OJTP was investigated in vivo using the DHBV-DNA-infected duckling model. During this experimental period, no significant side effects were observed in animals receiving antiviral therapy, neither were the control group. The levels of serum viral DNA was analyzed by dot hybridization and recorded in the five groups before the experiment (day 0). OJTP at dosage of $0.10 \mathrm{~g} \mathrm{~kg}^{-1} \mathrm{~d}^{-1}$ and $0.20 \mathrm{~g} \mathrm{~kg}^{-1} \mathrm{~d}^{-1}$ significantly inhibited DHBV DNA in duck serum. Densitometric quantitation of the dots revealed a significant decrease in DHBV and there were no significant differences in DHBV-DNA level between any of the controls. As shown in Table 3, with the exception of the control group, serum levels of DHBV-DNA of each group decreased with different extents after treatment with OJTP and 3TC on days 5 and 10, respectively. Among these, the OJTP $0.10 \mathrm{~g} \mathrm{~kg}^{-1} \mathrm{~d}^{-1}, 0.20 \mathrm{~g} \mathrm{~kg}^{-1} \mathrm{~d}^{-1}$, group and the 3TC group showed a significant decrease of DHBV-DNA $(P<0.01)$. Three days after the cessation of treatment with 3TC, the viral replication level return to the pretreatment baseline, whereas the effect of DHBV-DNA inhibition lasted with the ducks treated with OJTP (Table 3). The mean percentage inhibition of viral DNA levels with OJTP $0.10 \mathrm{~g} \mathrm{~kg}^{-1} \mathrm{~d}^{-1}$ and $0.20 \mathrm{~g} \mathrm{~kg}^{-1} \mathrm{~d}^{-1}$ was $52.91 \%$ and $56.82 \%$, $52.91 \%$ and $64.13 \%$, on days 5 and 10 , respectively.

Table 1

Inhibitory effect of OJTP on the expression of HBeAg in Hep G2.2.15

\begin{tabular}{|c|c|c|c|c|c|}
\hline \multirow[t]{2}{*}{ Group } & \multirow[t]{2}{*}{ Dose $\left(\mathrm{gL}^{-1}\right)$} & \multicolumn{2}{|l|}{ Day 6} & \multicolumn{2}{|l|}{ Day 9} \\
\hline & & $(\mathrm{cpm} / \mathrm{Bq}) \times 10^{3}$ & Inhibition (\%) & $(\mathrm{cpm} / \mathrm{Bq}) \times 10^{3}$ & Inhibition (\%) \\
\hline Control & 0 & $7.74 \pm 0.49$ & - & $9.31 \pm 0.54$ & - \\
\hline $3 \mathrm{TC}$ & 0.10 & $3.03 \pm 0.16^{* *}$ & 60.88 & $3.20 \pm 0.28^{* *}$ & 65.63 \\
\hline \multirow[t]{4}{*}{ OJTP } & 0.05 & $5.84 \pm 0.41^{* *}$ & 18.29 & $6.07 \pm 0.17^{* *}$ & 33.08 \\
\hline & 0.10 & $4.90 \pm 0.59^{* *}$ & 31.24 & $4.01 \pm 0.32^{* *}$ & 54.00 \\
\hline & 0.20 & $4.10 \pm 0.14^{* *}$ & 42.17 & $3.10 \pm 0.56^{* *}$ & 66.70 \\
\hline & 0.40 & $3.42 \pm 0.32^{* *}$ & 51.84 & $2.61 \pm 0.35^{* *}$ & 71.97 \\
\hline
\end{tabular}

The data represent mean \pm S.D. $(n=9)$. Symbols represent statistical significance.

** $P<0.01$ compared to control group.

Table 2

Inhibitory effect of OJTP on the expression of HBsAg in Hep G2.2.15

\begin{tabular}{|c|c|c|c|c|c|}
\hline \multirow[t]{2}{*}{ Group } & \multirow[t]{2}{*}{ Dose $\left(\mathrm{g} \mathrm{L}^{-1}\right)$} & \multicolumn{2}{|l|}{ Day 6} & \multicolumn{2}{|l|}{ Day 9} \\
\hline & & $(\mathrm{cpm} / \mathrm{Bq}) \times 10^{3}$ & Inhibition (\%) & $(\mathrm{cpm} / \mathrm{Bq}) \times 10^{3}$ & Inhibition (\%) \\
\hline Control & 0 & $11.24 \pm 1.70$ & - & $10.78 \pm 0.77$ & - \\
\hline $3 \mathrm{TC}$ & 0.10 & $3.41 \pm 0.54^{* *}$ & 67.47 & $3.15 \pm 0.32^{* *}$ & 70.07 \\
\hline \multirow[t]{4}{*}{ OJTP } & 0.05 & $9.23 \pm 1.86^{*}$ & 13.44 & $8.59 \pm 0.67^{* *}$ & 14.44 \\
\hline & 0.10 & $7.82 \pm 1.10^{* *}$ & 26.12 & $6.00 \pm 0.51^{* *}$ & 40.71 \\
\hline & 0.20 & $5.47 \pm 1.95^{* *}$ & 40.05 & $3.22 \pm 0.15^{* *}$ & 70.12 \\
\hline & 0.40 & $3.56 \pm 1.19^{* *}$ & 54.54 & $2.95 \pm 0.12^{* *}$ & 72.61 \\
\hline
\end{tabular}

The data represent mean \pm S.D. $(n=9)$. Symbols represent statistical significance.

${ }^{*} P<0.05$.

** $P<0.01$ compared to control group. 
Table 3

Inhibitory effect of OJTP on duck serum DHBV-DNA level

\begin{tabular}{|c|c|c|c|c|c|}
\hline \multirow[t]{2}{*}{ Group } & \multirow[t]{2}{*}{ Dose $\left(\mathrm{g} \mathrm{kg}^{-1} \mathrm{~d}^{-1}\right)$} & \multicolumn{4}{|l|}{ OD } \\
\hline & & Day 0 & Day 5 & Day 10 & Day 13 \\
\hline Control & - & $1.58 \pm 0.15$ & $1.58 \pm 0.175$ & $1.51 \pm 0.19$ & $1.53 \pm 0.13$ \\
\hline $3 \mathrm{TC}$ & 0.10 & $1.55 \pm 0.12$ & $0.70 \pm 0.09^{\# \#, * *}$ & $0.52 \pm 0.07^{\# \#,{ }^{* *}}$ & $0.90 \pm 0.04^{\# \#, * *}$ \\
\hline \multirow[t]{3}{*}{ OJTP } & 0.10 & $1.48 \pm 0.11$ & $1.28 \pm 0.16^{*}$ & $1.25 \pm 0.1^{*}$ & $1.23 \pm 0.08^{* *}$ \\
\hline & 0.20 & $1.53 \pm 0.13$ & $0.90 \pm 0.09^{\# \#,{ }^{* *}}$ & $0.72 \pm 0.08^{\# \#, * *}$ & $0.66 \pm 0.10^{\# \#, * *}$ \\
\hline & 0.40 & $1.54 \pm 0.15$ & $0.74 \pm 0.09^{\# \#,{ }^{* *}}$ & $0.55 \pm 0.06^{\# \#, * *}$ & $0.51 \pm 0.10^{\# \#, * *}$ \\
\hline
\end{tabular}

The data represent mean \pm S.D. $(n=6)$. Symbols represent statistical significance.

\#\# $P<0.01$ compared to day 0 .

${ }^{*} P<0.05$.

${ }^{* *} P<0.01$ compared to control group.

\subsection{Histopathological features}

Typical photographs of liver sections by light microscope are shown in Fig. 2. Histopathological profiles of the liver from the control group ducklings revealed necrosis, inflammatory cell infiltration and massive ballooning degeneration of the hepatic cytoplasm. The protective effect of OJTP was confirmed by histopathological examinations. Administration of OJTP to the experimental animals $\left(0.10 \mathrm{~g} \mathrm{~kg}^{-1} \mathrm{~d}^{-1}\right.$ and $\left.0.20 \mathrm{~g} \mathrm{~kg}^{-1} \mathrm{~d}^{-1}\right)$ showed a significant improvement of the hepatocellular architecture over the control group, as evident from a considerable reduction in inflammatory cell infiltration and ballooning degeneration.

\section{Discussion}

Hepatitis B is an infectious disease of the liver caused by HBV. Globally, about two billion people have been infected by HBV and approximately 350 million people are chronic carriers of HBV (Lamivudine, 2004). These carriers are at high risk for development of HBV-associated diseases, including liver cirrhosis, liver failure and hepatocellular carcinoma (HCC) and more than one million carriers die from these diseases each year (Ayoola et al., 1998). In China, the prevalence of HBV infection is very severe, with an estimated 120 million chronically infected carriers, up to 12 million suffering from chronic hepatitis B (Custer et al., 2004). Currently, there are mainly two arms of therapy to manage chronic active hepatitis
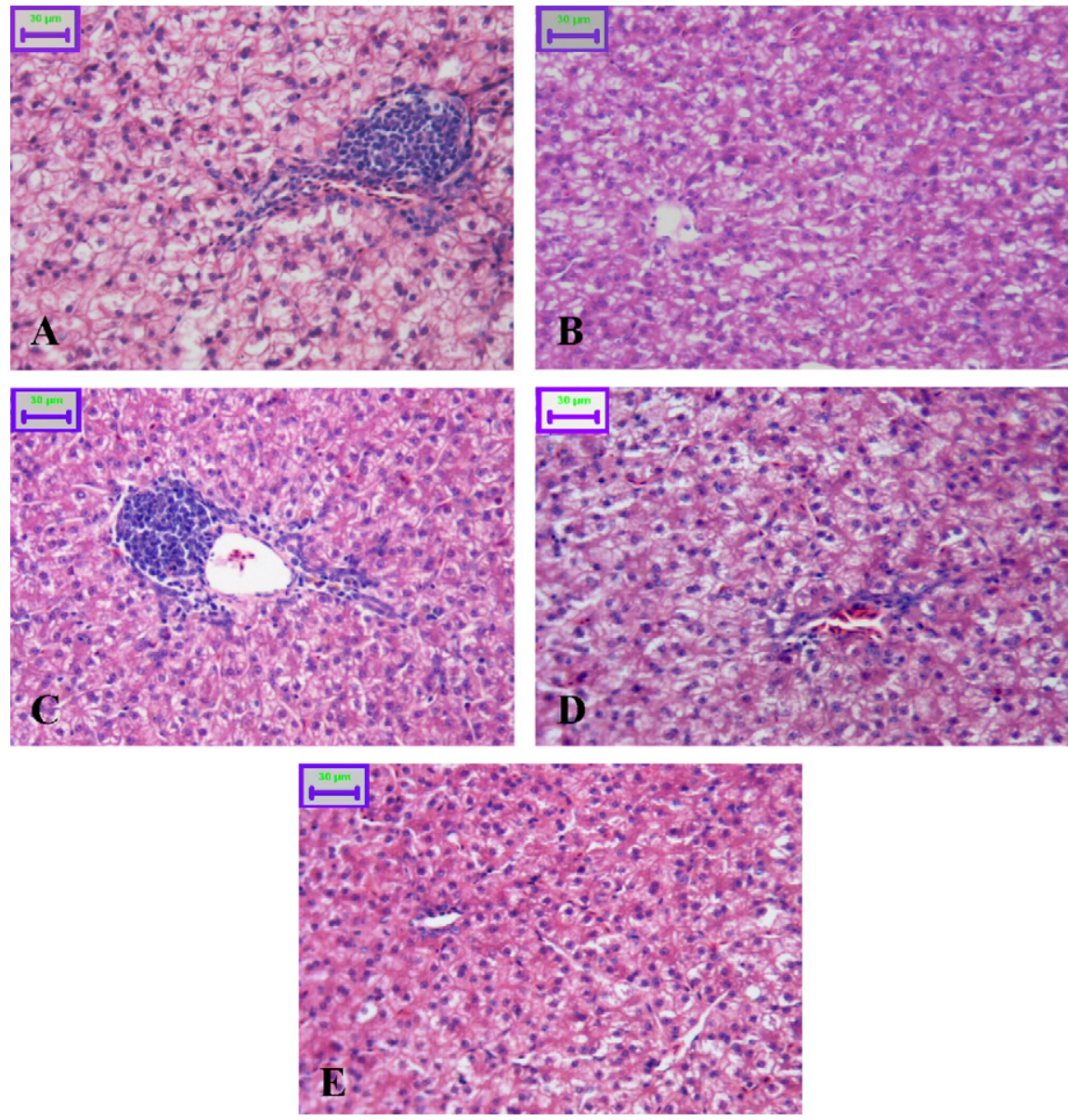

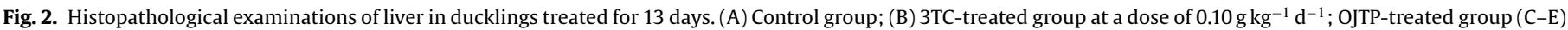
at a dose of $0.05 \mathrm{~g} \mathrm{~kg}^{-1} \mathrm{~d}^{-1}, 0.10 \mathrm{~g} \mathrm{~kg}^{-1} \mathrm{~d}^{-1}$ and $0.20 \mathrm{~g} \mathrm{~kg}^{-1} \mathrm{~d}^{-1}$, respectively. Hematoxylin-eosin staining (magnification: $10 \times 20$ ). 
$\mathrm{B}$ : one is direct antiviral therapy to inhibit replication of HBV and another is indirect immunomodulatory therapy to enhance cellular immunity to destroy the virus-infected hepatocytes.

Due to the low efficiency and many limitations of immunomodulatory therapy with IFN- $\alpha$, direct antiviral therapy could have been of greater importance. However, although direct antiviral therapy with drug just like Lamivudine and Adefovir could efficiently control chronic active hepatitis $B$, drug resistance or renal toxicity could develop progressively after several months of the initiation of therapy (Liaw et al., 2000; Leung et al., 2001; Schif et al., 2003). Therefore, the need to identify effective anti-HBV agents is still urgently required.

As is widely known, the nonhuman host range of HBV is restricted to a few animals, such as chimpanzee, several cell lines were developed to identify potential therapeutics against HBV replication. Hep G2.2.15 cell contains multiple copies of the HBV genome, which are stably integrated into the host cell genome (Sells et al., 1987, 1988) and is widely used as a useful "in vitro" model for evaluation of novel anti-HBV drugs. So in our experiment, we chose the Hep G2.2.15 cell line as in vitro cellular model. Our results indicate that OJTP inhibited $\mathrm{HBeAg}$ and $\mathrm{HBsAg}$ in a dose-and-time dependent manner. At $0.40 \mathrm{~g} / \mathrm{L}$, the inhibition rate of OJTP on $\mathrm{HBeAg}$ and HBsAg in Hep G2.2.15 were $70.12 \%$ and $72.61 \%$ on day 9 , and was more potent than 3TC at dosage of $0.10 \mathrm{~g} / \mathrm{L}$ (65.63\% and $70.07 \%$, respectively, on day 9 ) (Tables 1 and 2).

In contrast to the in vitro analysis of antiviral activity, the evidence from in vivo investigation may be regarded as more convincing. At present time, the most classical animal model in anti-HBV therapy is duck hepatitis B model (Yang et al., 2001), so the Beijing ducklings infected with DHBV were chosen as animal model and the inhibitory effect of OJTP in the duck HBV model was investigated. At the dose tested: $0.10 \mathrm{~g} \mathrm{~kg}^{-1} \mathrm{~d}^{-1}$ and $0.20 \mathrm{~g} \mathrm{~kg}^{-1} \mathrm{~d}^{-1}$, OJTP significantly decreased DHBV replication with the inhibition rate $53 \%$ and $64 \%$, respectively, on day 10 (date not shown). However, the anti-HBV effect of OJTP lasted for at least 10 and 3 more days after termination of treatment in ducks, indicating that the in vivo anti-HBV effect of OJTP was relatively long-lasting in ducks as compared with the effect of 3TC. The relatively rapid rebound of serum HBV DNA level in 3TC-treated ducks has been reported previously (Marion et al., 2002). This long duration of OJTP's activity may have significant clinical implications, and further supports the significance of developing OJTP into an anti-HBV drug. The in vivo anti-HBV activity was confirmed by histopathological improvement (Fig. 2) in the liver. Histopathological analysis of duckling liver revealed that the OJTP could meliorate the inflammatory cell infiltration in liver in a short time; it also had a definite effect on alleviating hepatocytes ballooning degeneration.

Data in this report clearly showed that OJTP inhibits DHBV production both in vivo and in vitro. Our results also indicate that OJTP shows no significant effect on host cells and animals. Since OJTP inhibits not only DHBV DNA replication but also HBV antigen expression, it is important to note that there might be at least two targets of OJTP, according to the concept that the regulation of viral replication is quite different from that of the expression of HBV antigen. Inhibition of HBsAg and HBeAg secretion may be achieved at the transcription, translation, or post-translational level. Although the replication and life cycle of HBV is complex, most known antiviral agents with activity against HBV act at the polymerase or reverse transcriptase (Lee et al., 1989; Price et al., 1989; Doong et al., 1991). OJTP may cause intracellular retention of HBV DNA by inhibition of HBV polymerase activity.

To sum up, the present study demonstrated that OJTP has potent anti-HBV activity in vitro and in vivo, and it was one of the main active parts of Oenanthe javanica against HBV. These findings might suggest another therapeutic option to manage chronic
HBV infection in the future. However, the final potential therapeutic mechanism of OJTP on anti-HBV was still unclear until now. Therefore, further investigation is required to determine the mechanism of anti-HBV activity of OJTP, and identification of the active components in OJTP will greatly enhance the understanding of viral gene expressions and provide new clues to assist the development of antiviral agents in the future.

\section{Acknowledgements}

This project was supported by Chinese National Foundation for Natural Sciences (No. 30170994). We thank Zhuang Li (the Institute of Medicinal Biotechnology, Chinese Academy of Medical Sciences, Beijing, China) for his excellent technical supports in this study. Plus, we also would like to give our thanks to Dr. Yan-Ling Zhao (302 Hospital of PLA, Beijing, China) for her support and cooperation in terms of cell culture.

\section{References}

Ayoola, E., Balayab, M.S., Deinhardt, F., et al., 1998. Progress in the control of viral hepatitis: Memorandum from a WHO meeting. Bulletin of World Health Organization 66, 443-455.

Custer, B., Sullivan, S.D., Hazlet, T.K., et al., 2004. Global epidemiology of hepatitis B virus. Journal of Clinical Gastroenterology 38, S158-S168.

Doong, S.L., Tsai, C.H., Schinazi, R.F., Liotta, D.C., Cheng, Y.C., 1991. Inhibition of the replication of hepatitis B virus in vitro by $2^{\prime}, 3^{\prime}$-dideoxy-3'-thiacytidine and related analogues. Proceedings of the National Academy of Sciences of the United States of America 88, 8495-8499.

Huang, Z.M., Yang, X.B., 2006. Model Study and Clinic Application of Anti-hepatitis Chinese Herbal Medicine. Zheng Zhou University Press, Zheng Zhou, China, pp. 35-39.

Huang, Z.M., Zhang, Z.M., Yang, X.B., 1997. Study of Shui Qin on antihepatitis. Pharmacology Clinics Chinese Materia Medica 7, 11-13.

Huang, Z.M., Yang, X.B., Cao, W.B., 1997a. Inhibition of Shui Qin on DHBV in vitro. Chinese Pharmaceutical Journal 32, 720-723.

Huang, Z.M., Yang, X.B., Cao, W.B., 1997b. Study of inhibition of duck hepatitis B virus by extract from Oenanthe javanica. Chinese Science Bulletin 42, 1863-1867.

Huang, Z.M., Yang, X.B., Cao, W.B., 2001a. Effects of Qin Ling Ke Li in the treatment of 90 patients with chronic hepatitis B. Pharmaceutical Journal of Chinese People's Liberation Army 17, 41-44.

Huang, Z.M., Yang, X.B., Cao, W.B., 2001b. Modern study and clinic application of Oenanthe javanica. Pharmaceutical Journal of Chinese People's Liberation Army 17, 266-269.

Lamivudine Clinical Practice Group, 2004. Lamivudine treatment consensus from relative experts. Chinese Journal of Hepatology 12, 425-427.

Lee, B., Luo, W.X., Suzuki, S., Robins, M.J., Tyrrell, D.L., 1989. In vitro and in vivo comparison of the abilities of purine and pyrimidine $2^{\prime}, 3^{\prime}$-dideoxynucleosides to inhibit duck hepadnavirus. Antimicrobial Agents and Chemotherapy 33, 336-339.

Leung, N.W., Lai, C.L., Chang, T.T., 2001. Extended lamivudine treatment in patients with chronic hepatitis B enhances hepatitis B and antigen seroconversion rates: results after 3 years of therapy. Hepatology 33, 1527-1532.

Li, S.Z., 1978. Compendium of Materia Medica. People’s Medical Publishing House, Beijing, China, pp. 1632-1633.

Liaw, Y.F., Leung, N.W., Chang, T.T., 2000. Effects of extended lamivudine therapy in Asian patients with chronic hepatitis B. Gastroenterology 119, 172-180.

Liu, J.P., Mclntosh, H., Lin, H., 2001. Chinese medicinal herbs for chronic hepatitis B. Cochrane Database Systematic Reviews 1, CD001940.

Marion, P.L., Salazar, F.H., Winters, M.A., Colonno, R.J., 2002. Potent efficacy of entecavir (BMS-200475) in a duck model of hepatitis B virus replication. Antimicrobial Agents and Chemotherapy 46, 82-88.

Mosmann, T., 1983. Rapid colorimetric assay for cellular growth and survival: application to proliferation and cytotoxicity assays. Journal of Immunological Methods 65, 55-63.

Price, P.M., Banerjee, R., Acs, G., 1989. Inhibition of the replication of hepatitis B virus by the carbocyclic analogue of 2-deoxyguanosine. Proceedings of the National Academy of Sciences of the United States of America 86, 8541-8544.

Sadasivam, S., Manikam, A., 1992. Biochemical Methods for Agricultural Sciences. Wiley Eastern Limited, New Delhi, p. 187.

Schif, E.R., Lai, C.L., Hadziyannis, S., et al., 2003. Adefovir dipivoxil therapy for lamivudine-resistant hepatitis B in pre-, and post-liver transplantation patient. Hepatology 38, 1419-1427.

Sells, M.A., Chen, M.L., Acs, G., 1987. Production of hepatitis B virus particles in Hep G2 cells transfected with cloned hepatitis B virus DNA. Proceedings of the National Academy of Sciences of the United States of America 84, 1005-1009.

Sells, M.A., Zelent, A., Shvartsman, M., Acs, G., 1988. Replicative intermediates of hepatitis B virus in HepG2 cells that produce infectious virions. Journal of virology $62,2836-2844$. 
Slinkard, K., Singleton, V.L., 1977. Total phenol analysis: automation and comparison with manual methods. American Journal of Enology and Viticulture 28 49-55.

Wei, W.P., 1963. Shen Nong's Herbal. People's Medical Publishing House, Beijing, China, pp. 128-129.

Yang, X.B., Huang, Z.M., Cao, W.B., 2001. Effect of an aqueous extract from Oenanthe javanica on rat cardiovascu1ar system. China Traditional Herb Drugs 10, 47-49.
Yang, S.L., Zhang, F.X., Zhu, Y.T., et al., 2001. Screening duck models with congenital infection of duck hepatitis B virus by polymerase chain reaction method. Journal of Guangzhou University of Traditional Chinese Medicine 18, 256-259.

Yan-Ling, O., Ze-Lin, L., Yi, Z., 2007. Effect of Chinese medicine extract Ren Xian Cao on the replication of hepatitis B virus. World Journal of Gastroenterology 15, 394-398. 